\title{
Copper and Magnesium Deficiency are Associated with Osteoporosis in Southern Gaza Patients
}

\author{
Mahmoud I. Elhabiby, \\ Department of Medical Laboratory Sciences, \\ Al-Aqsa University, Gaza, Palestine \\ Ayman M. Abu Mustafa, \\ Palestine college of Nursing, Ministry of Health, Gaza \\ Abdelmarouf H. Mohieldein, \\ College of Applied Medical Sciences, \\ Qassim University, Kingdom of Saudi Arabia \\ Esraa M. Elnabaheen, \\ Department of Medical Laboratory Sciences, \\ Al-Aqsa University, Gaza, Palestine
}

Doi:10.19044/esj.2020.v16n21p196 URL:http://dx.doi.org/10.19044/esj.2020.v16n21p196

\begin{abstract}
Osteoporosis is a common disease in old ages, trace minerals are central components of bone density and hardness. The present study aims to measure copper, magnesium, iron, calcium and phosphorus levels in osteoporotic southern Gaza patients and control groups. A case -control study included 35 osteoporotic patients and 35 controls aged 40-70 years. Copper, magnesium iron, calcium and phosphorus levels were measured in the serum at Palestinian Medical Relieve Society-Gaza by absorption spectrophotometry method-XLFS Kit (Diasys Diagnostic System GmbH). Serum copper and magnesium levels in osteoporotic patients $(74.3 \pm 9.8 \mu \mathrm{g} / \mathrm{dL} 1.56 \pm 0.18 \mathrm{mg} / \mathrm{dl})$ respectively is significantly $(\mathrm{p}<0.001)$ lower than control $\quad(98.3 \pm 15.2 \mu \mathrm{g} / \mathrm{dL}$, $2.06 \pm 0.13 \mathrm{mg} / \mathrm{dl})$. The present work indicated a positive correlation between copper and magnesium levels $(\mathrm{r}=0.627, \mathrm{p}<0.00)$, positive correlation between copper and number of daily meals $(\mathrm{r}=0.263, \mathrm{p}<0.030)$, and also positive correlation between calcium and daily exercises $(\mathrm{r}=0.449, \mathrm{p}<0.010)$. In conclusion copper and magnesium levels are significantly lower in postmenopausal women and men with osteoporosis. Optimizing levels of those trace minerals in old people is beneficial in prevention of osteoporosis. Daily exercises and ingestion of food containing trace minerals is highly recommended for this age group.
\end{abstract}

Keywords: Osteoporosis, Copper, Magnesi, Gaza 


\section{Introduction}

Osteoporosis is a systemic skeletal disease characterized by low bone mass and minerals deterioration of bone tissue, with a consequent increase in bone fragility and susceptibility to fractures, all individuals if they live long enough will develop osteoporosis; some due to various illnesses or as part of hormonal deficiency. It occurs as because of unbalance between bone formation and bone resorption. Many risk factors have been identified for osteoporosis including genetic factors, race, sex, age, menopausal state, smoking, medications, alcohol intake, exercise and nutrition (Srivastava \& Deal, 2002, Odabasi, et al., 2008, Pepa and Brandi, 2016). Osteoporosis affects millions people worldwide, predominantly postmenopausal women. (Castiglional et al., 2013). It is estimated that over 200 million people worldwide have osteoporosis. Although osteoporosis is more common in women than in men, the incidence in men is increasing. The prevalence of osteoporosis is continuing to escalate with the increasingly elderly population. (Reginster\& Burlet, 2006). The increase of life expectancy and so the old age in the society in developing countries such as the Middle East has led to an increase in the prevalence of osteoporosis (Memon, 1998). Dietary intake is an important modifiable factor for bone health. The process of bone formation requires an adequate and constant supply of nutrients, such as calcium, protein, magnesium, phosphorus, vitamin $\mathrm{D}$, potassium, and fluoride. However, there are several other vitamins and minerals needed for metabolic processes related to bone, including manganese, copper, boron, iron, zinc, vitamins A, K, C, and B complex (Srivastava et al., 2002). Trace elements such as iron, magnesium, manganese, zinc, copper, and iodine, that occur in very small amounts in organisms and are essential for many physiological and biochemical processes are affected in osteoporosis individuals. Magnesium $(\mathrm{Mg})$ appears to be important in bone cell activity. It is shown to be mitogenic for osteoblasts and its depletion causes cellular growth inhibition, in vitro (Odabasi, et al., 2008). Razmandeh et al. (2014) compared trace elements (Zinc, Copper and Magnesium) concentration in nail, urine and serum among osteoporotic postmenopausal women with control group in Iran. The urine level of trace elements had significant difference between osteoporotic groups and controls ( $\mathrm{p}<0.001)$. Moreover, $\mathrm{Mg}$ level significantly differed in serum between the two groups $(\mathrm{p}<0.04)$. There was no statistically significant difference in trace minerals in nail beyond groups. Mahdavi Roshan et al., 2015 founded that serum levels of zinc and copper were significantly $(\mathrm{p}<0.05)$ lower than normal range and $40 \%$ of participants had serum magnesium level lower than normal range; they recommended magnesium, zinc, calcium and cupper supplementation (Mahdavi-Roshan et al., 2015).

Serum concentrations of magnesium, zinc and copper were measured in postmenopausal women with osteoporosis $(n=40)$, osteopenia; an early 
stage of osteoporosis $(n=40)$ or normal bone mineral density $(n=40)$. Mean concentrations of magnesium and zinc were significantly lower in osteoporotic women than in both osteopenic women and normal women. There were no significant differences observed between the osteopenic, osteoporotic and control groups with respect to copper levels (Mutlu et al., 2007). Odabasi and others measured magnesium ( $\mathrm{Mg}$ ), zinc, copper, manganese, and selenium by atomic absorptions spectrophotometry in both postmenopausal women with osteoporosis and healthy postmenopausal women. Only statistically significant difference between the osteoporotic (51.51 [15.40] $\mu \mathrm{g} / \mathrm{mL})$ and healthy subjects $(54.54[15.42] \mu \mathrm{g} / \mathrm{mL})$ was observed in red blood cell $(\mathrm{RBC})$ magnesium concentration $(\mathrm{Z}=-2.07, \mathrm{P}=$ 0.039) (Odabasi et al., 2008).

Sahmani compare the serum levels of zinc $(\mathrm{Zn})$, copper $(\mathrm{Cu})$ and lipid profile between the postmenopausal women suffering from osteoporosis and the healthy controls. The serum levels of $\mathrm{Zn}$ and $\mathrm{Cu}$ were similar in both groups $(\mathrm{P}>0.05)$. Serum levels of low-density lipoprotein (LDL) and total cholesterol (TC) in osteoporosis group was significantly higher when compared to the controls $(\mathrm{P}<0.05)$. Correlation analysis showed that there was significant association between body mass index (BMI) and BMD values $(\mathrm{P}<$ 0.05). There was no correlation between serums $\mathrm{Zn}, \mathrm{Cu}$ levels with lipid profile $(\mathrm{P}>0.05)$. However, they found a negative significant correlation between BMD with LDL $(\mathrm{r}=-0.31, \mathrm{P}=0.001)$ and total cholesterol levels $(\mathrm{r}=-$ 0.26, $\mathrm{P}=0.006$ ) (Sahmani et al., 2014).

Stendig-Lindbergl et al. (1993) investigated the effect of magnesium treatment on trabecular bone density in postmenopausal osteoporosis. No new fractures occurred. Twenty-two patients $(71 \%)$ responded by a $1-8 \%$ rise of bone density. The mean bone density of all treated patients increased significantly after 1 year $(\mathrm{P}<0.02)$ and remained unchanged after 2 years $(\mathrm{P}>$ 0.05). The mean bone density of the responders increased significantly both after one year $(\mathrm{P}<0.001)$ and after 2 years $(\mathrm{P}<0.02)$, while in untreated controls the mean bone density decreased significantly $(\mathrm{P}<0.001)$. Magnesium therapy, which had no ill effects, prevented fractures and resulted in significant increase of bone density in $71 \%$ and arrest of bone loss in another $16 \%$ of the patients holds great promise in postmenopausal osteoporosis treatment. Pan et al. (2017) determined the role of IDA as a risk factor for osteoporosis by analyzing a large nationwide population-based sample. In a sample of 1,000,000 randomly sampled individuals from the 1998-2012. Taiwan National Health Insurance Research Database, patients with IDA (case group $(n=35,751))$ and individuals without IDA (control group $(n=178,755)$ ) were compared. Compared with individuals without IDA, the risk for osteoporosis was even higher for patients with IDA who received intravenous ferrum therapy (adjusted $\mathrm{HR}=2.21 ; 95 \% \mathrm{CI}=1.85-2.63$ ). In contrast, the risk 
for osteoporosis was reduced for patients with IDA who received a blood transfusion (adjusted $\mathrm{HR}=1.47 ; 95 \% \mathrm{CI}=1.20-1.80$ ). As a predictor, prior IDA is a significant and independent risk factor for development of osteoporosis.

The Palestinian Osteoporosis Prevention Society conducted a study on the prevalence of osteoporosis among postmenopausal women, they found that around $40 \%$ of postmenopausal women were affected (Abd-Alhameed et al., 2010). Trace studies are carried out on osteoporotic patients in Gaza Strip regarding trace minerals levels. Assessment of copper, iron, phosphorus, magnesium and calcium levels in osteoporotic patients; has not been performed in Gaza Strip; hence this study aimed to evaluate levels of these trace minerals in those patients. However, this work aimed to study the relationship between levels of copper, iron, phosphorus, magnesium and calcium and occurrence of osteoporosis in southern Gaza patients, in relation to dietary habits and life style.

Objectives: To study the relationship between copper, iron, phosphorus, magnesium and calcium levels and occurrence of osteoporosis in southern Gaza patients. Also to investigate the correlation between trace minerals levels and dietary habits and life style in osteoporotic patients.

Materials and Methods Study design and subjects: The present study is a case-control study. The study populations are osteoporotic patients aged 40-70 years attending osteoporotic clinics at European Gaza Hospital Southern Gaza Strip. Controls will be apparently healthy non osteoporotic individuals. Non probability accidental sample of 35 osteoporotic patients, at European Gaza Hospital, Southern Gaza Strip. 35 apparently healthy nonosteoporotic controls will be selected from the general population. Cases and controls will be age and gender matched. Osteoporotic patients aged <40 and $>70$ years and chronic conditions like heart disease, renal failure, malignancy are excluded from the study.

Blood sampling: For each participant, $5 \mathrm{ml}$ of blood was collected by venipuncture in a plain vacutainer for serum preparation to determine hormonal profile and HbA1c. The collected blood samples were allowed to clot at room temperature, and serum was separated by centrifugation at 3000 RPM for $10 \mathrm{~min}$ and stored at $-20^{\circ} \mathrm{C}$ until analysis.

Data collection and biochemical analysis: Subjects data is collected through Questionnaire interview. Ethical consideration A request letter to execute the study was sent to Palestinian Ministry of Health administration from Al-Aqsa-University. The study was carried out according to principles of Helsinki Declaration. Participation was voluntary, and participants were given a full explanation about the goals of the study. Confidentiality of all participants was maintained. 
Statistical analysis Data analyses were performed using the Statistical Package for the Social Sciences (SPSS) software (version 17). Continuous data were expressed as mean \pm standard deviation whereas categorical data as number (\%). Comparison of variables between cases and controls was performed with an unpaired t-test for continuous data and Chi-square for categorical data. Pearson correlation coefficients were calculated for trace minerals and lifestyle. $\mathrm{P}<0.05$ was considered statistically significant.

Methods: The commercial kits for trace minerals measurement were purchased from DiaSys Diagnostic Systems, Holzhein, Germany.

Determination of Calcium Principle: Calcium with arsenazo III at neutral $\mathrm{pH}$ yields a blue colored complex, whose intensity is proportional to the calcium concentration. Interference by magnesium is eliminated by addition of 8-hydroxyquinoline-5-sulfonic acid (Endres, et al., 1999, Michaylova, et al., 1971).

Determination of Phosphorus Principle: Inorganic phosphorus reacts ammonium molybdate in an acidic medium to form a phosphomolybdate complex. Maximum complex absorption is at $340 \mathrm{~nm}$. (Endres, et al., 1999, Burtis, et al., 1999)

Determination of Iron Principle: Iron bound to transferrin is released in an acidic medium as ferric iron and is then reduced to ferrous iron in the presence of ascorbic acid. Ferrous iron forms a blue complex with Ferene. The absorbance at $595 \mathrm{~nm}$ is directly proportional to the iron conc. (Guder, et al., 2001, Young, 2000)

Determination of Copper Principle: Colorimetric test without

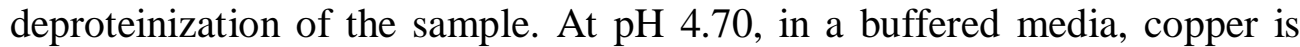
released from ceruloplasmine complex and form the specific comlexant3-5 DiBr-PAESA a stable colored complex. The color intensity is proportional to the amount of copper in the sample. (Brutis, et al., 1999, Kaplan, et al., 1984) Determination of Magnesium Principle: Magnesium in alkaline solution reacts with the chromogenxylidyl Blue to form a purple complex. The presence of glycoletherdiaminotetr acetic acid (GEDTA) that binds calcium ions in the reagent allows the reaction to be specific. Purple color intensity at $520 \mathrm{~nm}$ is proportional to the concentration of magnesium in the sample (Thomas, 1998, Chitto et al., 1994, Khvedelidze et al., 2019 ).

Results: The present study included 70 individuals divided into two groups, 35 patients Of osteoporosis aged from30-75 years and the second group 35 healthy subjects aged from 30-75 years to act as a control group. Table 1 showed similar physical and socioeconomic characteristics of the study population 
Table 1: Physical and Socioeconomic characteristics of the study population

\begin{tabular}{|c|c|c|c|c|c|}
\hline \multicolumn{2}{|c|}{ General characteristics } & $\begin{array}{c}\text { Cases } \\
(\mathrm{n}=35)\end{array}$ & $\begin{array}{c}\text { Controls } \\
(n=35)\end{array}$ & Statistical test & P-value \\
\hline Age (years) & \multirow{4}{*}{$\begin{array}{l}\text { Mean } \pm \text { SD } \\
\text { (Min-max) }\end{array}$} & $\begin{array}{c}61.1 \pm 9.6 \\
(30-73)\end{array}$ & $\begin{array}{l}56.3 \pm 9 \\
(41-75)\end{array}$ & $\mathrm{t}=2.143$ & 0.036 \\
\hline Weight (cm) & & $\begin{array}{c}80.5 \pm 10.7 \\
(51-104)\end{array}$ & $\begin{array}{c}88.3 \pm 20.8 \\
(56-170)\end{array}$ & $\mathrm{t}=-1.959$ & 0.054 \\
\hline Height (cm) & & $\begin{array}{c}160.6 \pm 11.2 \\
(130-187)\end{array}$ & $\begin{array}{l}165.3 \pm 8.5 \\
(150-188)\end{array}$ & $\mathrm{t}=-1.982$ & 0.051 \\
\hline BMI $\left(\mathrm{Kg} / \mathbf{M}^{2}\right)$ & & $\begin{array}{c}31.6 \pm 5.9 \\
(19.9-53.3)\end{array}$ & $\begin{array}{c}32.5 \pm 8.0 \\
(18.3-58.8)\end{array}$ & $\mathrm{t}=-0.551$ & 0.583 \\
\hline $\begin{array}{c}\text { Employment } \\
\text { Yes } \\
\text { No }\end{array}$ & \multirow{6}{*}{$\mathrm{n}(\%)$} & $\begin{array}{c}6(17.1) \\
29(82.9)\end{array}$ & $\begin{array}{c}1(2.9) \\
34(97.1)\end{array}$ & 3.96 & 0.046 \\
\hline $\begin{array}{c}\text { Sex } \\
\text { Male } \\
\text { Females }\end{array}$ & & $\begin{array}{c}6(17.1) \\
29(82.9)\end{array}$ & $\begin{array}{c}6(17.1) \\
29(82.9)\end{array}$ & $\chi^{2}=0.000$ & 1.000 \\
\hline $\begin{array}{c}\text { Age (years) } \\
<55 \\
55-65 \\
>65 \\
\end{array}$ & & $\begin{array}{c}9(25.7) \\
13(37.1) \\
13(37.1)\end{array}$ & $\begin{array}{c}17(48.6) \\
12(34.3) \\
6(17.1) \\
\end{array}$ & $\chi^{2}=5.080$ & 0.079 \\
\hline $\begin{array}{c}\text { Family history } \\
\text { No } \\
\text { Yes }\end{array}$ & & $\begin{array}{l}23(65.7) \\
12(34.30\end{array}$ & $\begin{array}{l}17(48.6) \\
18(51.4)\end{array}$ & 2.10 & 0.147 \\
\hline $\begin{array}{c}\text { Marital status } \\
\text { Married } \\
\text { Single }\end{array}$ & & $\begin{array}{c}33(94.3) \\
2(5.7)\end{array}$ & $\begin{array}{c}33(94.3) \\
2(5.7)\end{array}$ & $\chi^{2}=0.000$ & 1.000 \\
\hline $\begin{array}{c}\text { Exposure to } \\
\text { sun } \\
\text { No } \\
\text { Few } \\
\text { Often } \\
\text { Usually } \\
\text { Always }\end{array}$ & & $\begin{array}{c}1(2.9) \\
3(8.6) \\
10(28.6) \\
5(14.3) \\
16(45.7)\end{array}$ & $\begin{array}{c}3(8.6) \\
2(5.7) \\
10(28.6) \\
10(28.6) \\
10(28.6)\end{array}$ & $\chi^{2}=4.251$ & 0.373 \\
\hline
\end{tabular}

${ }^{*} \mathrm{P}$-value significant at $\mathrm{p} \leq 0.05$; n: number of the subjects; NIS: new Israeli shekel \& $\chi^{2}$ : chi-square test. BMI: Body mass index; $\mathbf{t}$ : student t-test

Table 2 showed the distribution of the dietary habits and life style among the study population, there were no significant differences between the two groups; but in the daily exercise there was a significant difference ( $p=0.003$ ); were $80 \%$ of control do the daily exercise but only $45.7 \%$ of cases do this activity. In addition, there was a significant difference $(p=0.002)$; between the two groups in the number of fractures were $60 \%$ of cases suffer from fractures but only $22.9 \%$ of control suffer from this condition. 
Table 3 showed the trace minerals level among the study population; there was a significant differences between the two groups; in copper (cases 74.3 \pm 9 . $\mu \mathrm{g} / \mathrm{dL} \quad 8$, control $98.3 \pm 15.2 \mu \mathrm{g} / \mathrm{dL}$ ) and magnesium (cases $1.56 \pm 0.18 \mathrm{mg} / \mathrm{dL}$ but control $2.06 \pm 0.13 \mathrm{mg} / \mathrm{dL}$ ). Levels judged by $\mathrm{p}$ value of $<0.001$ but there was no significant differences in the levels of iron, calcium and phosphorus.

Table 2: Dietary habits and life style among the study population

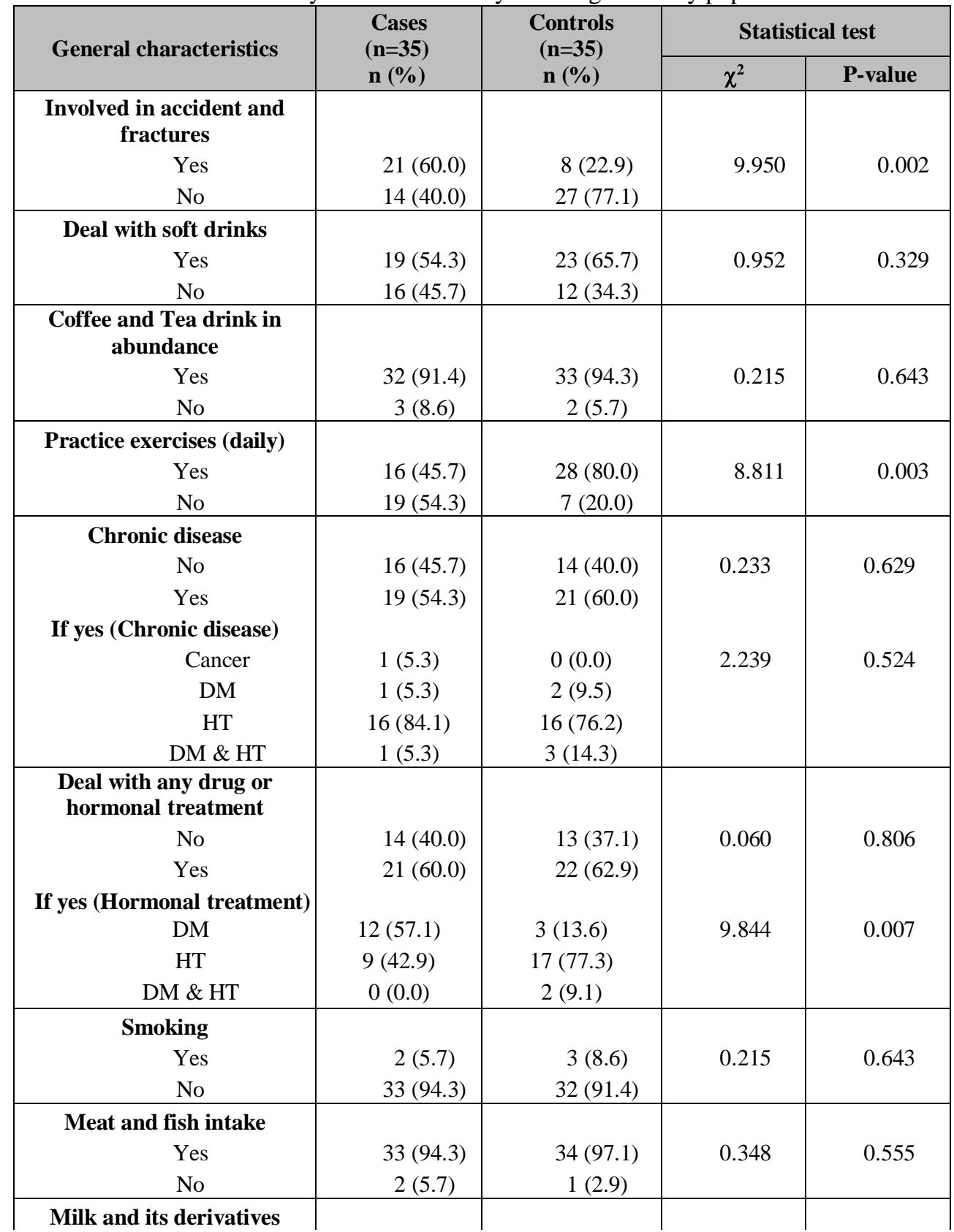




\begin{tabular}{|c|c|c|c|c|} 
Yes & $\begin{array}{c}26(74.3) \\
\text { No }\end{array}$ & $\begin{array}{c}30(85.7) \\
5(14.3)\end{array}$ & 1.429 & 0.232 \\
\hline Number of eggs in week & $32(91.4)$ & $30(85.7)$ & 0.565 & 0.452 \\
Yes & $3(8.6)$ & $5(14.3)$ & & \\
No & & & & \\
\hline $\begin{array}{c}\text { Fruits and vegetables in } \\
\text { take }\end{array}$ & $34(97.1)$ & $34(97.1)$ & 0.000 & 1.000 \\
Yes & $1(2.9)$ & $1(2.9)$ & & \\
No & $3(8.6)$ & $0(0.0)$ & 3.082 & 0.214 \\
One & $21(60.0)$ & $23(69.7)$ & & \\
Two & $11(31.4)$ & $10(30.3)$ & & \\
Third & Number of meals (daily) & & & \\
\hline
\end{tabular}

"P-value significant at $\mathrm{p} \leq 0.05$; n: number of the subjects;

DM: Diabetes mellitus; HT: Hypertension $\& \chi^{2}$ : chi-square test.

Table 3: Trace minerals among the study population

\begin{tabular}{|c|c|c|c|c|c|}
\hline \multirow{2}{*}{ Parameters } & \multirow{2}{*}{$\begin{array}{c}\text { Cases } \\
(\mathbf{n}=35) \\
\text { Mean } \pm \text { SD }\end{array}$} & \multirow{2}{*}{$\begin{array}{c}\text { Controls } \\
(\mathbf{n}=35) \\
\text { Mean } \pm \text { SD }\end{array}$} & \multicolumn{3}{|c|}{ Statistical test } \\
\hline & & & $\begin{array}{c}\% \\
\text { difference }\end{array}$ & $\mathbf{t}$ & P-value \\
\hline $\begin{array}{l}\text { Cu }(\boldsymbol{\mu g} / \mathbf{d L}) \\
(\operatorname{Min}-\max )\end{array}$ & $\begin{array}{l}74.3 \pm 9.8 \\
(60-96.5)\end{array}$ & $\begin{array}{c}98.3 \pm 15.2 \\
(58.6- \\
132.4)\end{array}$ & -27.8 & -7.823 & $\begin{array}{c}< \\
0.001\end{array}$ \\
\hline $\begin{array}{c}\mathbf{M g}(\mathbf{m g} / \mathbf{d L}) \\
(\operatorname{Min}-\max )\end{array}$ & $\begin{array}{l}1.56 \pm 0.18 \\
(1.4-2.47)\end{array}$ & $\begin{array}{c}2.06 \pm 0.13 \\
(1.68-2.48)\end{array}$ & -27.8 & -13.081 & $\begin{array}{c}< \\
0.001\end{array}$ \\
\hline $\begin{array}{c}\text { Fe }(\boldsymbol{\mu g} / \mathbf{d L}) \\
(\operatorname{Min}-\max )\end{array}$ & $\begin{array}{c}55.8 \pm 24.1 \\
(26-141)\end{array}$ & $\begin{array}{l}50.8 \pm 21.9 \\
(21.4-109)\end{array}$ & 4.7 & 0.904 & 0.369 \\
\hline $\begin{array}{l}\text { Ca (mg/dL) } \\
(\text { Min - max) }\end{array}$ & $\begin{array}{c}8.8 \pm 0.4 \\
(8-9.7)\end{array}$ & $\begin{array}{c}8.9 \pm 0.4 \\
(8-9.7)\end{array}$ & -0.5 & -0.862 & 0.392 \\
\hline $\begin{array}{l}\text { Ph (mg/dL) } \\
(\text { Min - max) }\end{array}$ & $\begin{array}{c}3.4 \pm 0.5 \\
(2.6-4.8)\end{array}$ & $\begin{array}{c}3.3 \pm 0.6 \\
(2.4-4.8)\end{array}$ & 1.5 & 0.751 & 0.455 \\
\hline
\end{tabular}

${ }^{*}$ P-value significant at $\mathrm{p} \leq 0.05$; n: number of the subjects; SD: standard deviation,

t: student t-test; Cu: Copper; Ph: phosphorus; Fe: iron; Mg: Magnesium \& Ca: Calcium

Table 4 separated the cases and control according to the normality of trace minerals levels. This table indicated a-significant differences in the cases and control in the levels of copper and magnesium. In cases, $40 \%$ suffer from low level of copper but only $2.9 \%$ of control suffer from low copper level. Also $74.3 \%$ of cases suffer from low magnesium level but no one suffer from low magnesium level on the control. There was no significant differences in the levels of iron, calcium and phosphorus in control and cases. 
Table 4: Trace minerals among the study population

\begin{tabular}{|c|c|c|c|c|}
\hline \multirow[b]{2}{*}{ Parameters } & \multirow{2}{*}{$\begin{array}{l}\text { Cases } \\
(\mathbf{n}=35) \\
\mathrm{n}(\%)\end{array}$} & \multirow{2}{*}{$\begin{array}{c}\begin{array}{c}\text { Controls } \\
(\mathbf{n}=35) \\
\mathbf{n}(\%)\end{array} \\
\end{array}$} & \multicolumn{2}{|c|}{ Statistical test } \\
\hline & & & $\chi^{2}$ & P-value \\
\hline $\mathbf{C u}(\mu \mathrm{g} / \mathrm{dL})$ & & & & \\
\hline Low & $14(40.0)$ & $1(2.9)$ & 14.339 & $<0.001$ \\
\hline Normal & $21(60.0)$ & $34(97.1)$ & & \\
\hline $\mathbf{M g}(\mathrm{mg} / \mathrm{dL})$ & & & & \\
\hline Low & $26(74.3)$ & $0(0.0)$ & 41.364 & $<0.001$ \\
\hline Normal & $9(25.7)$ & $35(100.0)$ & & \\
\hline $\mathbf{F e}(\mu \mathrm{g} / \mathrm{dL})$ & & & & \\
\hline Low & $8(22.9)$ & $11(31.4)$ & 0.650 & 0.420 \\
\hline Normal & $27(77.1)$ & $24(68.6)$ & & \\
\hline Ca $(\mathrm{mg} / \mathrm{dL})$ & & & & \\
\hline Low & $9(25.7)$ & $7(20.0)$ & 0.324 & 0.569 \\
\hline Normal & $26(74.3)$ & $28(80.0)$ & & \\
\hline $\mathbf{P h}(\mathrm{mg} / \mathrm{dL})$ & & & & \\
\hline Low & $1(2.9)$ & $5(14.3)$ & 2.917 & 0.088 \\
\hline Normal & $34(97.1)$ & $30(85.7)$ & & \\
\hline
\end{tabular}

*P-value significant at $\mathrm{p} \leq 0.05 ; \mathbf{n}$ : number of the subjects; $\chi^{2}$ : chi-square test; Cu: Copper;

Ph: phosphorus; Fe: iron; Mg: Magnesium \& Ca: Calcium

Table 5 shows the results of the correlation between trace minerals, dietary habits and life style in the studied parameters, it shows a negative correlation between calcium and Phosphorus ( $\mathrm{r}=-0.735$, Figure 1), positive correlation between copper and magnesium levels ( $\mathrm{r}=0.627$, Figure 2), a positive correlation between number of meals and copper level ( $\mathrm{r}=0.263$, Figure 3), also a positive correlation between calcium level and the daily exercise ( $\mathrm{r}=0.449$, Figure 4$)$.

Table 5: Correlation between trace minerals, dietary habits and life style in the studied parameters

\begin{tabular}{|c|c|c|c|c|c|c|c|c|c|c|}
\hline \multirow{2}{*}{ Parameters } & \multicolumn{2}{|c|}{$\begin{array}{c}\mathbf{P h} \\
(\mathrm{mg} / \mathrm{dL})\end{array}$} & \multicolumn{2}{|c|}{$\begin{array}{c}\mathbf{C u} \\
(\mu \mathrm{g} / \mathrm{dL})\end{array}$} & \multicolumn{2}{|c|}{$\begin{array}{c}\mathbf{F e} \\
(\mu \mathrm{g} / \mathrm{dL})\end{array}$} & \multicolumn{2}{|c|}{$\begin{array}{c}\mathbf{C a} \\
(\mathrm{mg} / \mathrm{dL})\end{array}$} & \multicolumn{2}{|c|}{$\begin{array}{c}\mathbf{M g} \\
(\mathrm{mg} / \mathrm{dL})\end{array}$} \\
\hline & $\mathbf{r}$ & P-value & $\mathbf{r}$ & $\begin{array}{c}\text { P- } \\
\text { value }\end{array}$ & $\mathbf{r}$ & $\begin{array}{c}\mathrm{P}- \\
\text { value }\end{array}$ & $\mathbf{r}$ & $\begin{array}{c}\text { P- } \\
\text { value }\end{array}$ & $\mathbf{r}$ & $\begin{array}{c}\text { P- } \\
\text { value }\end{array}$ \\
\hline $\mathbf{P h}(\mathrm{mg} / \mathrm{dL})$ & - & - & 0.022 & 0.855 & 0.098 & 0.418 & -0.735 & 0.000 & 0.002 & 0.985 \\
\hline $\mathbf{C u}(\mu \mathrm{g} / \mathrm{dL})$ & 0.022 & 0.855 & - & - & -0.147 & 0.224 & -0.055 & 0.649 & $\mathbf{0 . 6 2 7}$ & 0.000 \\
\hline $\mathbf{F e}(\mu \mathrm{g} / \mathrm{dL})$ & 0.098 & 0.418 & -0.147 & 0.224 & - & - & 0.014 & 0.911 & -0.094 & 0.441 \\
\hline Ca $(\mathrm{mg} / \mathrm{dL})$ & -0.735 & 0.000 & -0.055 & 0.649 & 0.014 & 0.911 & - & - & -0.032 & 0.795 \\
\hline $\mathbf{M g}(\mathrm{mg} / \mathrm{dL})$ & 0.002 & 0.985 & 0.627 & 0.000 & -0.094 & 0.441 & -0.032 & 0.795 & - & - \\
\hline Age (years) & 0.140 & 0.248 & -0.110 & 0.364 & -0.046 & 0.703 & -0.230 & 0.056 & -0.124 & 0.307 \\
\hline Weight $(\mathrm{cm})$ & 0.081 & 0.505 & 0.171 & 0.158 & -0.112 & 0.356 & -0.092 & 0.447 & 0.209 & 0.082 \\
\hline Height $(\mathrm{cm})$ & 0.085 & 0.486 & 0.106 & 0.382 & 0.040 & 0.742 & -0.015 & 0.902 & 0.188 & 0.119 \\
\hline BMI $\left(\mathrm{Kg} / \mathrm{md}^{2}\right)$ & 0.029 & 0.812 & 0.082 & 0.501 & -0.130 & 0.284 & -0.090 & 0.458 & 0.069 & 0.573 \\
\hline $\begin{array}{l}\text { Number of } \\
\text { meals (daily) }\end{array}$ & 0.157 & 0.201 & 0.263 & 0.030 & -0.121 & 0.324 & -0.125 & 0.308 & 0.113 & 0.358 \\
\hline $\begin{array}{c}\text { Frequency } \\
\text { Coffee and Tea } \\
\text { drink in } \\
\end{array}$ & -0.125 & 0.328 & 0.091 & 0.479 & 0.170 & 0.183 & 0.190 & 0.137 & -0.108 & 0.398 \\
\hline
\end{tabular}




\begin{tabular}{|c|c|c|c|c|c|c|c|c|c|c|}
\hline $\begin{array}{c}\text { abundance } \\
\text { (daily) }\end{array}$ & & & & & & & & & & \\
\hline $\begin{array}{c}\text { Frequency } \\
\text { practice daily } \\
\text { exercises } \\
\text { (weekly) }\end{array}$ & -0.203 & 0.266 & 0.199 & 0.275 & -0.171 & 0.349 & 0.449 & 0.010 & 0.304 & 0.091 \\
\hline $\begin{array}{c}\text { Frequency } \\
\text { intake meat } \\
\text { and fish } \\
\text { (weekly) }\end{array}$ & 0.009 & 0.941 & 0.049 & 0.693 & -0.021 & 0.868 & 0.069 & 0.575 & -0.098 & 0.426 \\
\hline $\begin{array}{c}\text { Frequency } \\
\text { intake milk and } \\
\text { its derivatives } \\
\text { (weekly) }\end{array}$ & -0.048 & 0.723 & 0.115 & 0.393 & -0.021 & 0.877 & 0.031 & 0.819 & 0.107 & 0.428 \\
\hline $\begin{array}{c}\text { Frequency } \\
\text { intake eggs } \\
\text { (weekly) }\end{array}$ & -0.012 & 0.923 & 0.149 & 0.249 & -0.103 & 0.427 & 0.007 & 0.956 & 0.004 & 0.973 \\
\hline $\begin{array}{c}\text { Frequency } \\
\text { intake fruits } \\
\text { and vegetables } \\
\text { (weekly) }\end{array}$ & 0.003 & 0.980 & 0.181 & 0.145 & -0.092 & 0.461 & -0.005 & 0.969 & 0.033 & 0.795 \\
\hline
\end{tabular}

${ }^{*}$ P-value significant at $\mathrm{p} \leq 0.05$; n: number of the subjects; BMI: Body mass index; Cu: Copper; Ph: phosphorus; Fe: iron; Mg: Magnesium; Ca: Calcium \& r: Pearson correlation

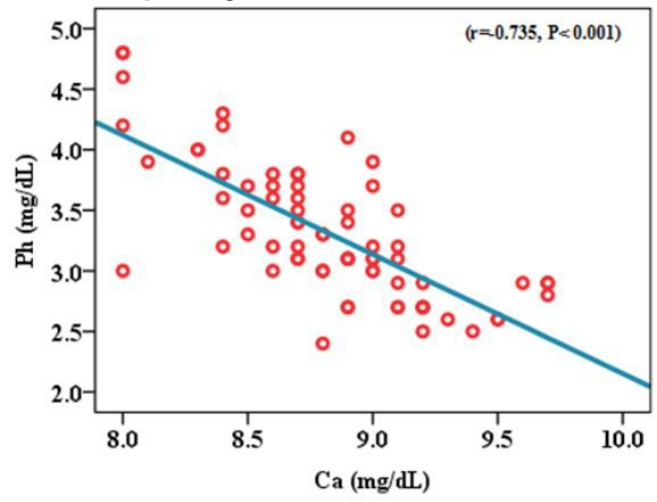

Figure (1): The negative correlation between $\mathrm{Ph}$ and $\mathrm{Ca}$.

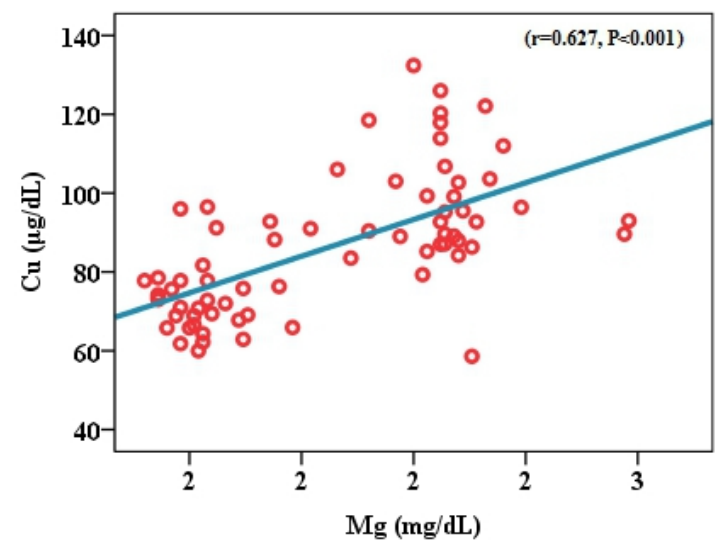

Figure (2): The positive correlation between $\mathrm{Mg}$ and $\mathrm{Cu}$. 


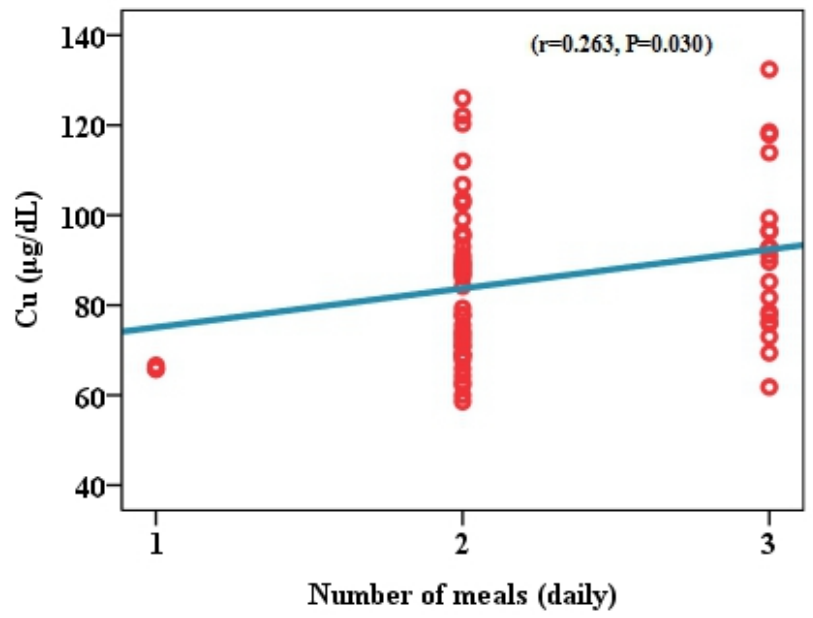

Figure (3): The positive correlation between number of meals and $\mathrm{Cu}$.

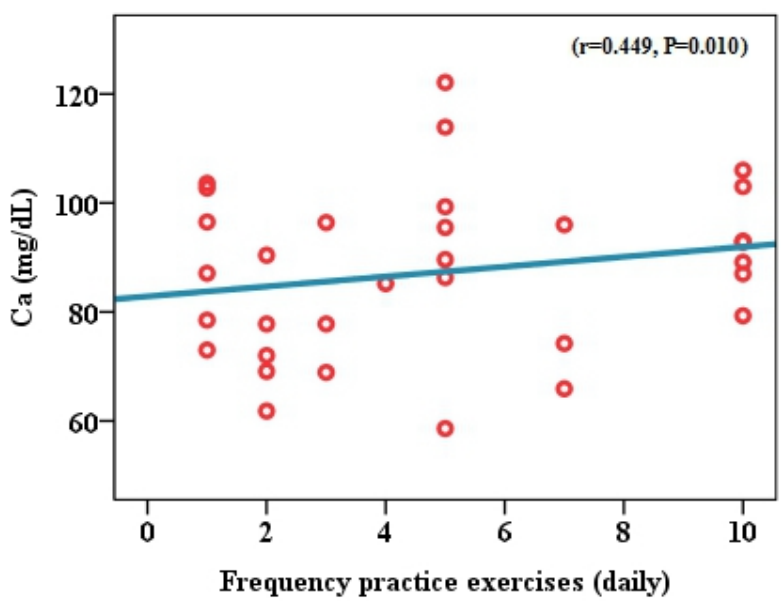

Figure (4): The positive correlation between frequency practice exercises and $\mathrm{Ca}$.

\section{Discussion}

The involvement of trace minerals in bone metabolism and osteoporosis have not yet been clarified. Numerous investigators recorded significant changes in trace minerals levels in osteoporotic patients. Calcium, magnesium and copper are essential for normal development of skeleton (Jan Aaseth et al., 2012). Iron is a component of hemoglobin; oxygen transport protein, phosphorus and calcium are essential components of bone, phosphorus is needed for energy production in all cells. Lack of calcium in the diet leads to a form of leaching out of bone mineral content (osteoporosis). Copper is an antioxidant, involved in protein metabolism, coenzymes for many enzymes, involved in healing processes. Magnesium is important in calcium and potassium hemostasis. Numerous biochemical and physiological processes require magnesium, including energy production,, protein 
syntheses, muscle contraction and vascular tone. Zinc and copper are essential cofactors for enzymes involved in the synthesis of various bone matrix constituents (Nicola M Lowe et al ., 2009). The causes of age related changes in bone mass are multifactorial and include genetic predisposition, nutritional factors endocrine changes habitual exercise levels and body weight. In the present study separation of cases and control according to their physical and socioeconomic characteristics does not show any significant differences between cases and control except in the percentage of employment patients $(17.1 \%)$ comparing with control $(2.9 \%),(\mathrm{p}=0.047)$. Also separation of cases and control according to dietary habits does not show any differences but life style shows a significant differences $(p=0.003)$ in the daily exercise, percentage of individuals exercise daily in cases $45.7 \%$ but in control $80 \%$ of individuals exercise daily ; the same result was gained by Chaconas, and Russ, , 2013). Table 4 shows a significant differences $(p<0.001)$ in copper and magnesium levels in cases and control (Figures 1 and 2), but levels of calcium, phosphorus and iron does not show any differences. Separation of cases and control according to the normality of trace minerals levels explain that $40 \%$ of cases have low copper level but $2.9 \%$ of control have low level this difference is statistically significant $\mathrm{p}=<0.001 .74 .3 \%$ of cases have low magnesium level but $0 \%$ of control have low level, $\mathrm{p}=<0.001$. For calcium, phosphorus and iron levels there are no differences between the studied groups.

Results of the present work is in agreement with the previous studies, Castiglioni and others; reported that level of magnesium is less than normal in women with postmenopausal osteoporosis (Castiglional et al., 2013, El habiby et al., 2017 ).

The present study recorded a significant negative correlation $(r=-$ $0.735, \mathrm{p}=0.000$, Figure 1) between calcium and phosphorus levels and a significant positive correlation $(r=0.627, p=0.00$, Figure 2) between magnesium and copper levels. In addition, the present work indicated a significant correlation between copper level and number of daily meals $(r=0.263, p=0.030$, Figure 3$)$, and a positive correlation between calcium level and daily exercise $(r=0.449, p=0.01$, Figure 4$)$. Copper is a cofactor for lysyl oxidase that required in cross-linking of collagen and elastin. $\mathrm{Cu}$ deficiency causes inhibition of bone growth and osteoporosis (Yee CD et al., 1995). In a more recent study, they recorded that magnesium deficiency is contributed to osteoporosis directly by acting on crystal formation and on bone cells and indirectly by affecting the secretion and activity of parathyroid hormone and by promoting low grade inflammation. Consequently, optimizing magnesium intake might represent an effective and low cost preventive measure against osteoporosis in individuals with documented magnesium deficiency (Castiglional et al., 2013). 
Gur A et al., 2002 indicated that serum values of $\mathrm{Mg}$, copper and $\mathrm{Zn}$ $(\mathrm{p}<0.05)$ were significantly lower in osteoporotic patients group than those in the control group. They suggested that calcitonin therapy regulates $\mathrm{Mg}, \mathrm{Cu}$, and $\mathrm{Zn}$ levels in postmenopausal osteoporosis, and when serum calcium and phosphorus were normal, $\mathrm{Mg}, \mathrm{Cu}$, and $\mathrm{Zn}$ were more useful for evaluation. Magnesium ( $\mathrm{Mg}$ ) appears to be important in bone cell activity and calcium metabolism. It is shown to be mitogenic for osteoblasts and its depletion causes cellular growth inhibition, in vitro (Razmandeh et al. 2014). Previous studies showed that Mg levels in 24-hours urinary excretion were increased in postmenopausal women compared with premenopausal women (Srivastava et al., 2002). Lee et al., (2014) evaluated the relationships between dietary calcium, phosphorus, calcium/phosphorus intake ratio, and bone mass in Korean adults. There were positive relationships between dietary calcium intake, calcium/phosphorus intake ratio and femoral neck BMD in men older than 50 years, and dietary calcium intake showed positive associations with BMD for whole body in premenopausal women. Madhavi-Roshan et al., (2015) showed that the mean dietary intake of magnesium, zinc and calcium in post-menopausal women with low bone density were significantly lower than recommended dietary allowance. The mean serum levels of zinc $(\mathrm{P}=$ $0.001)$ and copper $(\mathrm{P}=0.000)$ were significantly lower than normal range and $40.4 \%$ of this participants had serum magnesium levels lower than normal range. $\mathrm{Mg}, \mathrm{Zn}$ and $\mathrm{Cu}$ are necessary for the transmission of nerve impulses, temperature regulation, detoxification, energy production, and the formation of healthy bones and teeth. Sierpinskaj et al., (2014) recorded that enamel in adult individuals with severe tooth wear is low in copper content. The causes of osteopenia and osteoporosis are multifactorial, involving genetics, endocrine function, exercise, life style, disease status, metabolic factors, age, BMI, rheumatoid arthritis, smoking status, alcohol status and nutritional considerations. Results of the present study is comparable to the results of our previous study carried out on patients from northern Gaza we recorded a relationship between osteoporosis and many risk factors such as daily inactivity, ages, hormonal therapy and coffee drink (Elhabiby et al., 2017). Element deficiency may occur for several reasons; deficiencies are primarily due to renal wasting and are exacerbated by dietary element deprivation, gastrointestinal losses with diarrhea or vomiting, as well as concomitant use of drugs such as diuretics and aminoglycosides. Element deficiency may contribute to increased bone loss due to its effects on mineral homeostasis, trace element supplementation up to the recommended daily allowance, especially with $\mathrm{Mg}, \mathrm{Zn}$ and $\mathrm{Cu}$, may have beneficial effects on bone density. High $\mathrm{Zn}$ and $\mathrm{Mg}$ foods may be beneficial in post-menopausal women (Stendig-Lindbergl et al,. 1993, Srivastava et al., 2002, Madhavi-Roshan et al., 2015, Elhabiby et al., 2017). 
The recommended daily intake of magnesium necessary for bone health in young people under 30 years of age is $400 \mathrm{mg}$, in older subjects it is $320 \mathrm{mg}$ and $420 \mathrm{mg}$ for females and males, respectively.

Castiglioni et al., 2013 suggested that several direct and indirect mechanisms contribute to the effects of low magnesium on bone density: low magnesium can directly affect the bone by altering the structure of apatite crystals; magnesium deficiency is also associated with reduction of PTH and 1,25 (OH2) D levels and low grade inflammation and endothelial dysfunction, with a well-known relation between inflammation and bone loss.

An extensive analysis by Hayhoe et al. (2015) in a large group of adult subjects of both genders showed that dietary magnesium and serum magnesium were positively associated with calcaneal bone ultrasound analysis in women and negatively associated with fracture risk in both women and men. Furthermore, magnesium supported facilitated postoperative healing in orthopedic patients, in whom degradable fixation magnesium devices were used (Chaya et al. 2015).

Deficiency or excess of $\mathrm{Zn} \mathrm{Cu}, \mathrm{Mn}, \mathrm{Mg}, \mathrm{Fe}$ Boron and cobalt influence bone mass and bone quality in adulthood as well as in childhood and adolescence. However, some protective elements may become toxic under certain conditions (Zofkova et al., 2017).

Xinhua et al., 2018 found that low concentration of serum copper lead to lower BMD whereas higher serum levels are associated with an increased risk of fracture, especially in men. Activity of lysyl oxidase for covalent crosslinking of collagen is copper ions dependent. Collagen is the mail component of bone tissue extracellular matrix (Ettinger, 2017). Recently they used copper containing mesoporous bioactive glass nano particles as multifunctional agent for bone regeneration (Bari et al., 2017). Elderly patients with fractures of the femoral neck were found to have significantly lower serum copper levels than age and sex matched controls (Conlan et al., 1990). Post-menopausal women with a high dietary calcium intake combined with a high serum copper level had a greater lumbar bone density than women with low calcium intake and low serum copper (Haward et al, 1990, Allagoa, 2018). Dietary copper is available in a wide variety of foods including meats, seafood, nuts and grains. The recommended daily intake of copper adequate for bone health in adults is $0.9 \mathrm{mg} /$ day (Charles et al., 2012).

Copper plays an important role in regulation of bone growth and development of the skeleton. The element induces the formation of lysine crosslinks in collagen and elastin via lysyl oxidase activation. As a cofactor of antioxidant enzymes, it removes bone free radicals that cause the osteoclast activation (Kubiak et al. 2010). In addition, copper inhibits osteoclastic bone resorption directly ( $\mathrm{Li}$ and $\mathrm{Yu}$ 2007). Altogether, copper increases bone strength and helps to maintain the optimal state of bone quality. The 
recommended daily intake of copper for adequate bone quality in adults is 0.9 mg/day (Price et al., 2012, Lrhorfi, 2016). Epidemiological studies and clinical trials showed micronutrients could potentially have a positive impact on bone health, preventing bone loss and fractures, decreasing bone resorption and increasing bone formation. Consequently, optimizing micronutrients intake might represent an effective and low-cost preventive measure against osteoporosis (Pepa et al., 2016, Ibrahim et al., 2017).

\section{Conclusion}

Copper and magnesium levels are significantly lower in postmenopausal women and men with osteoporosis. Optimizing levels of those trace minerals in old people is beneficial in prevention of osteoporosis. Daily exercises and ingestion of food containing trace minerals is recommended for all ages.

\section{References:}

1. Abd-Alhameed, I., Saba, E., \& Darwish, H. M. (2010). Prevalence and awareness of osteoporosis among postmenopausal Palestinian women. Archives of Osteoporosis, 5, 111-118.

2. Allagoa, D. O., Agbo, O. J., \& Orluwene, C. G. (2018). Comparative Evaluation of Serum Calcium and Magnesium Level in Preeclamptic and Non-Preeclamptic Women in a Tertiary Hospital in Southern Nigeria. . European Scientific Journal, 14 (437-451).

3. Bari A, Bloise N, Fioilli S, Novajra G, Vallet-Ragi M, Bruni G et al ., 2017 Copper containing mescoporous bioactive glass nano particles as multifunctional agent for bone regeneration Acta Biomateriallia, 55: 493-504

4. Burits CA, Ashwood ER editors. Tietz Textbook of Clinical chemistry 3rd edition Philadelphia W B. Saundders Company; 1999. P1829

5. Castiglioni, S., Cazzaniga, A., Albisetti, W., \& Maier, J. A. (2013). Magnesium and Osteoporosis: Current state of knowledge and Future Research Directions. Nutrients, 5(8), 3022-3033.

6. Chaconas, E. J., Olivencia, O., \& Russ, B. S. (2013). Exercise interventions for the individual with osteoporosis. Strength \& Conditioning Journal, 35(4), 49-55.

7. Charles T. Price, Joshua R. Langford and Frank A. Liporace 2012. Essential Nutrients for Bone Health and a Review of their Availability in the Average North American Diet. The Open Orthopaedics Journal.;6:143-149.

8. Chaya A, Yoshizawa S, Vverdelis K, Myers N, Costelio BJ, Chou DT, Pal S, MAIaitis S, Kumta PN, Sfeir C 2015. In vivo study of 
magnesium plate and screw degeneration and bone fracture healing. Acta Biomater 18: 262-269,

9. Chitto, G., Fabi, A., Franzini, C., Galletta, G., Leonardi, A., Marelli, M., \& Morelli, A. M. (1994). Variabilità biologica intraindividuo: rassegna della letteratura, contributo sperimentale e considerazioni critiche. Biochimica Clinica, 18(10), 673.

10. Conlan D, Korula R, Tallentire D. 1990. Serum copper levels in elderly patients with femoral-neck fractures. Age and Ageing.19:212214.

11. El-Habiby M I, Hammad S W, Abu Bakra H M, Mohieldein A H (2017) "Zinc and Magnesium Levels in Osteoporotic Patients from Northern Gaza Strip" IUG Journal of Natural Studies Peerreviewed Journal of Islamic University-Gaza ISSN 2409-4587 IUGNES, Special Issue, pp 148-154

12. Endres DB, Rude RK, Mineral and bone metabolism. In: Burits CA, Ashwood ER Tietz Textbook of Clinical chemistry 3rd edition Philadelphia W B. Saundders Company; 1999. P 1395-1406, 13951457

13. Ettinger S 2019 Chapter 9 , 9-osteoporosis and fracture risk in Nutritional Pathophysiology of obesity and its comorbidities Academic press $\mathrm{P}, 209-34$.

14. Ibrahim, A., Babandi, A., Tijjani, A. A., Murtala, Y., Yakasai, H. M., Shehu, D., ... \& Umar, I. A. (2017). In Vitro Antioxidant and AntiDiabetic Potential of Gymnema Sylvestre Methanol Leaf Extract. European Scientific Journal, 13, 218-238.

15. Guder WG Zawta B et al., Quality of diagnostic samples $1^{\text {st }}$ ed. Darmstadt: GIT Verlag; 2001; p 34-5

16. Gur Ali, Colpan L, Nas K, Cevik R Sarac J, Erdogan F and Duz Z (2002) the role of trace minerals in the pathogenesis of postmenopausal osteoiporosis and a new effect of calcitonin

17. Howard G, Andon M, Saltman P, Strause L. 1990. serum copper concentration, dietary calcium intake and bone density in postmenopausal women: cross-sectional measurements. Journal of Bone and Mineral Research. 5:S177.

18. Hayhoe R P G, Lentjes M A H, Luben R N., Khaw K. T., and Welch A A., (2015). "Dietary magnesium and potassium intakes and circulating magnesium are associated with heel bone ultrasound attenuation and osteoporotic fracture risk in the EPIC-Norfolk cohort study" Am J Clin Nutr ;102:376-84. U S A. American Society for Nutrition 
19. Jan Aaseth, Georges Boivin, Ole A "Osteolorosis and trace elemnetsAn Overview" Journal of trace elements in Medicine and Biology Vol. 26, Issue 2-3, 2012 P149-152

20. Kaplan A et al., Clin. Chem. The C V. Mosby Co. 1984

21. Kubiak K, Klimczak A, Dzikli L, Modranka R, Malinowska K 2010. Influence of copper (II) complex on the activity of selected oxidative enzymes. (In Polish) Pol Merkur Lekarski 28: 22-25,

22. Lee, K.J., Kim, K.S., Kim, H.N., Seo, J.A. and Song, S.W. (2014). "Association between dietary calcium and phosphorus intakes, dietary calcium/phosphorus ratio and bone mass in the Korean population".Nutrition Journal; 13:114.

23. Li BB, Yu SF. 2007. In vitro study of the effects of copper ion on osteoclastic resorption in various dental mineralized tissues. Zhoghua Kou Qiang Yi Xue Za Zhi. 42:110-3.

24. Lrhorfi, L. A., Dahmani, F. Z., Elyahyoui, O., Berrani, A., Samama, A., Kerrouri, S., \& Bengueddour, R. (2016). The Secondary Metabolites Composition of Extracts Genista Quadriflora of Morocco. European Scientific Journal, 79-88.

25. Khvedelidze, R., Kutateladze L., Sadunishvili, T., Zakariashvili, N., Darbaidze, Z., Aleksidze, T., (2019). Heat Stable $\alpha$ - and Glucoamylase Performing Deep Enzymatic Hydrolysis of Starch to Fermentable Glucose. European Scientific Journal, 15 : 21 (35 - 44).

26. Madhavi-Roshan, M., Ebrahimi, M. and Ebrahimi, A. (2015). "Copper, magnesium, zinc and calcium status in osteopenic and osteoporotic post-menopausal women". Clinical Cases in Mineral and Bone Metabolism; 12(1): 18-211.

27. Memon, A., Pospula, W.M., Tantawy, A.Y.(1998). "Incidence of hip fracture in Kuwait". International Journal Epidemiol; 27(5): 860-65.

28. Michaylova V IIkova P Photometric determination of micro amounts of calcium with arsenazoIII Anal Chim Acta 1971;53: 194-8

29. Mutlu, M., Argun, M., Kilic, E., Saraymen, R., \& Yazar, S. (2007). Magnesium, zinc and copper status in osteoporotic, osteopenic and normal post-menopausal women. Journal of International Medical Research, 35(5), 692-695

30. Nicola M Lowe, William D Fraser, Malcolm J Jackson (2009). Is there a potential therapeutic value of copper and zinc of osteoporosis? Proceedings of the Nutrition Society Vol 61, Issue 2

31. Odabasi, E., Turan, M., Aydin, A., Akay, C. and Kutlu, M. (2008). "Magnesium, zinc, copper, Manganese and selenium levels in postmenopausal women with osteoporosis can Magnesium play a key role in Osteoporosis". Ann Acad Me Singapore; 37:564-567. 
32. Pan, M.L., Chen, L.R., Tsao, H.M. and Chen, K.H. (2017). "Iron Deficiency Anemia as a Risk Factor for Osteoporosis in Taiwan: A Nationwide Population-Based Study". Nutrition Journal; 9:616.

33. Pepa GD and Brandi ML, 2016 Microelements for bone boost: the last but not the best Clinical cases in Minerals and Bone Metabolism 13 (3): 181-185

34. Price CT, Langfordt JR, Liporace FA 2012. Essential nutrients for bone health and a review of their availability in the average north american diet. Open Orthop J 6: 143-149,

35. Razmandeh, R., Nasli-Esfahani, E., Heydarpour, R., Faridbod, F., Ganjali, M.R., Noronzi, P., Larijani, B. and Khoda-amorzideh, D.K.(2014). "Association of zinc, copper and magnesium with bone mineral density in Iranian postmenopausal women -A case control study". Journal of Diabetes and Metabolic Disorders; 13:43.

36. Reginster, J.Y. and Burlet, N. (2006). WHO Collaborating Center for Public Health Aspects of Rheumatic Diseases, and Bone and Cartilage Research Unit. University of Liège, Belgium.

37. Sahmani, M., Osmidian, S., Javadi, A., Sabet, M.S. and Abbasi, M. (2014). "Association between the serum levels of zinc, copper and lipid profile with osteoporosis in Iranian postmenopausal women". Biotech Health Sci; 1(1):e19190

38. Sierpinska T., Konstantynowicz J., Orywal K., Golebiewska M., Szmitkowski M., (2014) "Copper deficit as a potential pathogenic factor of reduced bone mineral density and severe tooth wear" Osteoporos Int 25:447-454

39. Srivastava M. and Deal C. (2002) ."Osteoporosis in elderly: prevention andtreatment". ClinGeriatr Med. 18: 529- 555.

40. Stendig-Lindberg G. et al., (1993)."Trabecular bone density in a two year controlled trial of peroral magnesium in osteoporosis". MagnesiumResearch; 6(2):155-163.

41. Thomas, L. (1998). Clinical laboratory diagnostics. (1st ed.). Frankfurt, Germany: TH-Book Verlagsgesellschaft

42. Xinhua Qu, Zihao He, Han Qiao, Zanjing Zahai, Zhenyang Hao, zhifeng Yu and kerong Dai, 2018 Serum copper levels are associated with bone mineral density and total fractures. Journal of Orthopaedic Transplantation 14,34-44

43. Yee CD, Kubena KS, Walker M, Champney TH, Sampson HW. The relationship of nutritional copper to the development of postmenopausal osteoporosis in rats. Biol Trace Elem Res. 1995;48(1):1-11. doi: 10.1007/BF02789074. 
44. Young DS effect of Drugs on Clinical Laboratory tests. $5^{\text {th }}$ ed. Volume 1 and 2 Washington, DC: The American association for Clinical Chemistry Press 2000.

45. Zofkovai I. , Davis M., Blahos J., (2017). Trace Elements Have Beneficial, as Well as Detrimental Effects on Bone Homeostasis" Physiol. Res. 66: 391-402. 